\title{
Consensus and dissension in education in values. The collective construction of a hierarchy in a secondary school
}

\begin{abstract}
Value-based education is a top-level social concern and lies at the core of the educational process. Education centers are becoming increasingly aware of the need to design contextualized action plans that enable agreed and systematic interventions. An action plan must be based on a hierarchy of values that is supported by the entire educational community. In this article we introduce the diagnosis of the needs of a high school and the development of a value hierarchy for it. We used structured questionnaires to gather the opinion of the different sectors of the educational community-families, pupils and teachers. The results of our research reveal the points of agreement, disagreement and the priorities for each sector and other groups in their own right. Finally, we show how it was possible to agree on a single hierarchy of values that are represented by those sections and allowed for an action plan for that particular education center to be formulated.
\end{abstract}

Research Article

Volume 2 Issue I - 2018

\section{Fulgencio Sánchez Vera'}

Department of Didactics and School Organization, University of Murcia, Spain

Correspondence: Fulgencio Sánchez Vera, Department of Didactics and School Organization, University of Murcia, Murcia, Spain, Email f.sanchezvera@um.es

Received: February 07, 2018 | Published: February 28, 2018

Keywords: value based education, action research, secondary education

\section{Introduction}

The objective of institutionalized education is the construction of a subject in accordance with the dominant social model. As indicated by Schramm Martin ${ }^{1}$ every institutional educational project is inevitably determined by the type of man and society that is intended to be built. Consequently, to educate it is necessary to opt previously "for a system of values, since education has to be guided in a certain way of understanding man, life and the world. It is impossible to educate without a reference to the field of values"(p.267). Education in values is an inherent element in the educational process, so the centers and the teaching staff have to address it, because every teaching-learning process is wrapped in a set of norms and values and, in addition, it is a legal requirement. Not in vain, the social and civic competence, which is fundamentally linked to the development of ethical and civic values, is one of the basic competences that all students must achieve in compulsory education. ${ }^{2}$ However, the concept of "value" is slippery and complex; In fact, in the literature we find different approaches and nuances depending on the authors and the areas of knowledge. For the philosopher Ortega y Gasset, ${ }^{3}$ values are beliefs or deep convictions about things, others and ourselves, that guide our existence and in terms of which we make decisions. For the social psychologist Milton Rokeach, ${ }^{4}$ values are a type of lasting beliefs that order human behavior, because they indicate to the subject that a certain mode of behavior is personally or socially preferable to the opposite mode of behavior. For the anthropologist Ricardo Sanmartín ${ }^{5}$ the values are: "cultural models of certain great moral principles of behavior, appreciated by those who share them. Models slowly generated in the experience of the interaction throughout the story and that are transmitted when the actors in their social life exemplify them, incarnating them in the conduct, giving testimony of them" (p 130). We consider important to stress that values are a social construction, are a fundamental part of the culture of a people and found the basis of coexistence. The hierarchy of values that an individual or society possesses is linked to a certain conception of the world. In short, every value framework has a socio-historical and cultural origin; the values have been and are subject to a constant process of revision and improvement to adjust to the social reality and, very especially, to the awareness that a society, in a certain space and time, has reached on itself and on the world. ${ }^{6}$ We can conclude that values are criteria that guide us about what is right or wrong to feel, think or do, both consciously and unconsciously and, consequently, shape the behaviors, habits and customs of people. Thus understood, values are the frame of reference, the compass that guides and gives meaning to our individual and social life. Education in values is a social concern of the first order. From different areas, the need for the school to promote values in young people is stressed; But what values are the fundamental ones? Reaching an agreement on what values to educate may seem simple when approached from an ideal level (for example, we can all agree on the value of friendship, truth or justice); but, when we situate ourselves in the plane of concrete reality, of experience, the agreement vanishes: "divergences will arise when defining the concrete content of such perfection or optimization: what values, what sense and what hierarchical order are the basis of education, or the best education ". 7 The paradox is that, although everyone seems to be clear about the need to promote education in values, the coexistence in the centers is deteriorating and the conflict continues to increase. From this reality we can deduce that the institutional proposals to address education in values as specific subjects or the orientations to treat them as cross-cutting themes of the curriculum are not working or are not enough. Common sense and research point to the need to find consensus, creative and dynamic responses, the foundation of the democratic school that builds and contextualizes its own responses to the needs it meets. ${ }^{12-16}$ Various investigations show that school-family collaboration in the diagnosis of problems of coexistence and the possible actions to be carried out allow continuity to the lines of action 
of the center in homes, ${ }^{17-20}$ achieving a greater sense and cohesion of the actions. ${ }^{14-23}$ Likewise, for students to internalize a value and respect a rule, they must have the opportunity to participate in the determination of the importance of that value and in the elaboration of the rules that regulate the coexistence of the center and the classroom, of this way will be identified much more with its center, aspects that improve relationships and prevent abuse between colleagues. ${ }^{24,25}$ In this sense, based on the framework of values that, as a society, we have given, each center should have its own action plans, appropriate to their reality and widely agreed, where they establish which values are more urgent to address and how to do it. However, the inertia and the pressure of school activity to comply with the prescribed curriculum leave little room for this type of dynamics. Unfortunately, rarely, the entire educational community has the opportunity to get involved in a collective project to reflect and share visions and positions that guide joint action. That is why we feel it a privilege to have participated in an action-research project aimed at creating an action plan to promote education in values. In addition, we firmly believe that the monitoring of these collective reflection processes and their impact on the centers is a valuable knowledge and, therefore, it is the mission of educational research to describe, analyze and disseminate these experiences so that they transcend their space of application and thus favor the improvement of education. In this article we present part of the results of this research-action project carried out in a secondary school during the 2015/2016 academic year. It is a descriptive report that shows the consensus and disagreements among the different sectors and groups of the educational community and how, through a mathematical model created ad hoc and based on set theory, it was possible to generate a hierarchy of values that It reflects the great consensus while considering the particular opinions of all sectors and groups with their own entity within the educational community.

\section{Methodological framework}

As we have indicated, this study is part of an educational researchaction project aimed at developing an action plan to promote education in values. The research team of the project was formed by fifteen professors of the center and had the support and funding of the Ministry of Education, Research, Culture and Sports of the Valencian Community. ${ }^{1}$ The need for this plan is driven by the reality of the center, which has seen how in recent years the problems have not stopped increasing: fights in the playground, disruption in the classroom, lack of respect for teachers... no doubt, situations everyday in many educational centers. However, in the study center, during the 2015/2016 academic year, 267 students accumulated 1501 parts of incidents, 509 reprimands were made and 86 disciplinary proceedings were opened, alarming figures that mobilized the educational community in the search for a plan of action to address the problem.

\section{Objective}

The development of an action plan to promote values requires a hierarchy of values that supports it. Therefore, the first step is to determine a hierarchy of basic values that has a broad consensus among all the actors involved. This would be the objective of specific research where we focus the present study.

${ }^{1}$ The project has been funded by the Ministry of Education, Research, Culture and Sports of the Valencian Community, under the call for projects of research and educational innovation on the development of the curriculum (ORDER 11/2015, of September 28) [ DOCV 01/10/2015]
The research question that guides us is: What is the hierarchy of values that best represents the views of the school's educational community? And connected with this: What is the procedure to achieve it?

In this sense, the research team considers that, in order to achieve a hierarchy that represents the center, in the first place, it is necessary to consider the opinions of the different sectors and groups within the educational community. This assumption is specified in two design principles:

- Principle 1: The opinion of teachers, families and students must be considered equally.

- Principle 2: The hierarchy of each sector should reflect the internal opinions that may appear according to age groups, sex, educational level or others that are relevant. ${ }^{26}$

\section{Population and sample}

The research is carried out in a secondary school located in a municipality in the south of the Valencian Community (Spain). Its economy, traditionally supported by a powerful agricultural sector, is opening up to tourism, which is gaining more and more importance. In the last decades, the growth promoted by both economic sectors has fostered an important immigration of families coming mainly from North Africa, South America and Europe. The center, the only secondary school in the municipality, is publicly owned, has a staff of 90 teachers and welcomes about 1000 students that reflect the diversity of backgrounds, cultures and socioeconomic levels of the municipality. The center is a multicultural space where coexistence is built not without difficulty from the different beliefs, motivations and values of teachers, families and students. It should be noted that the center is classified as having a low socioeconomic and cultural level, and the academic results according to the diagnostic evaluation tests place it in the 23rd percentile in mathematical competence and the 15th percentile in the Spanish language, which means that it is in the lower levels within the Valencian Community. The target population is the families of the students who attend the center (approximately 700 ), the 90 teachers assigned to the school year and the 1000 students enrolled. For the sample selection, we use the following criteria:

1.That all levels of Secondary Education were represented: Compulsory Secondary Education (ESO) and Baccalaureate. ${ }^{2}$

2.That both students and families of Spanish origin and those of foreign origin were represented.

3.In order to obtain significant samples, we decided to pass the questionnaires to the entire faculty, to 300 students and their respective families.

\section{Instrument}

To address the objective, it is necessary to gather the diverse opinions, describe them and propose a basic set of values that represents the best possible agreement among all the sectors and groups of actors of the center. Therefore, it is not about explaining or analyzing the causes of these events, but presenting them and proposing a solution

${ }^{2}$ Secondary education in the Spanish system is divided into Compulsory Secondary Education (ESO), for students between 12 and 16 years, equivalent to Grade 7,8,9 and 10 of the American system; and the Baccalaureate that is equivalent to grade 11 and 12 . 
consistent with the objectives, leaving the interpretation of the causes open for further analysis. To collect the information, the chosen technique has been the survey, specifically, the questionnaire, since it is a technique that allows us to collect a high number of highly accurate answers and is perfectly suited to the type of descriptive research that we propose; In addition, we apply it transversally, since we intend to know all the cases of people with a certain condition at a given time. To this end, a structured Likert questionnaire was constructed. The design of the questionnaire was carried out through a discussion group formed by 15 professors who formed the research team. The questionnaire proposes 17 points to evaluate and leaves open the possibility that the interviewees add others that they consider relevant. The answers could take the following values:

0 . Does not know/does not answer

1. Nothing important

2. Little important

3. Important

4. Quite important

\section{5 . Very important}

The categories to be assessed (in bold) and the statement of the questionnaire are:

1. Equality: "Gender equality, real equality between men and women".

2. Cleaning: "Cleaning (order and urbanity)".

3. Affectivity: "Affectivity, ability to express feelings and emotions".

4. Assertiveness: "Assertiveness, ability to express their opinion and will firmly without aggressiveness. Be able to say 'No'.

5. Self-control: "Self-control, self-discipline".

6. Courtesy: "Courtesy and good manners."

7. Respect: "Respect for others."

8. Autonomy: "Autonomy (independence, self-sufficiency, selfconfidence)".

9. Reflection: "Capacity for critical reflection before everyday reality".

10. Empathy: "Empathy, ability to identify with someone and understand their feelings".

11. Sincerity: "Honesty and sincerity".

12. Forgiveness: "Ability to forgive and excuse".

13. Responsibility: "Recognize and take responsibility for our actions".

14. Pro-welfare: "Willingness to work for the welfare of others".

15. Courage: "Courage, ability to overcome fears and take risks."

16. Will: "Will, work habits and perseverance".

17. Interculturality: "Interculturality, recognizing the cultural diversity of the center as something enriching".
The questionnaire for teachers and families was the same, while for the students the wording of each statement was adapted to improve their comprehension. The questionnaires obtained a reliability of 0.86 using the Alpha of Cronbach Levene. We use the internal consistency method applying the indicated statistic, through the statistical package SPSS version 23.

\section{Data collection and analysis procedure}

The questionnaires for the families were accompanied by a letter signed by the director in which the object of the investigation was explained and the content and manner of completing it were explained. The tutors of each selected group were responsible for distributing and collecting the questionnaires. Finally, 424 surveys were collected: 65 from teachers, 86 from families and 273 from students. The surveys were coded and processed with the Statistical Package for the Social Sciences (SPSS) version 23 program. In a first step, an exploration was performed to debug and correct anomalous data and, subsequently, the appropriate data and reports were generated.

\section{Procedure to determine the hierarchies of values}

In order to achieve the hierarchy of values that best represents the opinions of the entire educational community, a procedure was agreed upon that complies with the two proposed design principles and is summarized in the following algorithm:

1. For each educational sector

a. Determine the global proposal of the sector considering the complete sample.

b. Determine differentiated proposals according to gender and other possible internal groupings, such as level of studies, age, nationality or course.

c. For each of the different hierarchies obtained, select the values with the highest score; specifically, it was agreed to take the five values with the highest score or those that are less than 0.5 points of the most valued.

d. To form the hierarchy of values of the sector, first select the values that result from the intersection of all the groups analyzed, followed by the values with the highest degree of intersection. The results of each intersection are ordered according to the global assessment of the sector.

2. The final hierarchy is conformed to the values that emerge from the intersection of the three educational sectors, followed by those that result from the intersection of two sectors and these, in turn, followed by the exclusive ones of a single sector. In each of the three cases, the values will be ordered according to their average score in the three sectors. With these criteria, the general consensus as well as the opinions of each sector and even possible internal groups that have sufficient entity, such as groupings according to gender, the level attended by the student or the age range of the professors is reflected in the final hierarchy.

\section{Results}

The data produced by the total sample are not considered, since the first design principle is not observed, since the sample of the students $(\mathrm{N}=273)$ would completely hide the opinions of other sectors with less population or less sample representation, as is the case with the 
professors $(\mathrm{N}=65)$ and families $(\mathrm{N}=86)$, when the objective is for the three sectors to have an equal weight in the conformation of the final hierarchy of values. A first approximation to this egalitarian treatment of the opinions of the three educational sectors could be based on the calculation of the arithmetic mean of the average results of each sector (Table 1). In this case, we would obtain the following hierarchy: Respect (4.62), Courtesy (4.28), Equality (4.27), Cleaning (4.24) and Responsibility (4.15) (Table 1).

Table I Average of the results of the global samples of the three educational sectors ( N, sample; DT, standard deviation; M, Medium)

\begin{tabular}{|c|c|c|c|c|c|c|c|c|c|c|c|c|c|c|c|c|c|c|}
\hline & $\begin{array}{l}\text { Medium/ } \\
\text { Standard } \\
\text { Desviation }\end{array}$ & $\begin{array}{l}\text { Equa- } \\
\text { lity }\end{array}$ & $\begin{array}{l}\text { Affec- } \\
\text { tivity }\end{array}$ & $\begin{array}{l}\text { Clea- } \\
\text { ning }\end{array}$ & $\begin{array}{l}\text { As- } \\
\text { ser- } \\
\text { tive- } \\
\text { ness }\end{array}$ & $\begin{array}{l}\text { Self- } \\
\text {-con- } \\
\text { trol }\end{array}$ & $\begin{array}{c}\text { Cour- } \\
\text { tesy }\end{array}$ & $\begin{array}{l}\text { Res- } \\
\text { pect }\end{array}$ & $\begin{array}{c}\text { Au- } \\
\text { to- } \\
\text { nomy }\end{array}$ & $\begin{array}{l}\text { Re- } \\
\text { flec- } \\
\text { tion }\end{array}$ & $\begin{array}{l}\text { Em- } \\
\text { pa- } \\
\text { thy }\end{array}$ & $\begin{array}{l}\text { Sin- } \\
\text { ceri- } \\
\text { ty }\end{array}$ & $\begin{array}{l}\text { For- } \\
\text { give- } \\
\text { ness }\end{array}$ & $\begin{array}{l}\text { Res- } \\
\text { ponsi- } \\
\text { bility }\end{array}$ & $\begin{array}{l}\text { Pro- } \\
\text { welfare }\end{array}$ & Courage & Will & $\begin{array}{l}\text { Intercultu- } \\
\text { rality }\end{array}$ \\
\hline \multirow{2}{*}{$\begin{array}{c}\begin{array}{c}\text { Families } \\
N=86\end{array} \\
\text { ( }\end{array}$} & M & 4,43 & 4,4 & 4 & 4,47 & 4,41 & 4,45 & 4,71 & 4,1 & 3,93 & 4,13 & 4,36 & 4,22 & 4,41 & 3,94 & 3,91 & 4,42 & 3,85 \\
\hline & DT & I,0I & 0,89 & 1,01 & 0,82 & 0,89 & 0,89 & 0,75 & 1,02 & 1,15 & 0,97 & 1,04 & 0,95 & 0,89 & 1,14 & 1,16 & 0,93 & 1,18 \\
\hline \multirow{2}{*}{$\begin{array}{l}\text { Student } \\
\mathrm{N}=273\end{array}$} & M & 4,47 & 4,22 & 3,71 & 4,13 & 3,71 & 4,07 & 4,36 & 3,88 & 3,4 & 3,94 & 3,98 & 3,81 & 4,01 & 2,66 & 3,45 & 3,67 & 3,88 \\
\hline & DT & 1,04 & 1,03 & 1,35 & 1,05 & 1,23 & 1,09 & 1,04 & 1,16 & 1,31 & 1,22 & 1,14 & 1,28 & 1,05 & 1,43 & 1,3 & 1,33 & 1,21 \\
\hline \multirow{2}{*}{$\begin{array}{l}\text { Faculty } \\
\mathrm{N}=65\end{array}$} & M & 3,91 & 4,09 & 3,51 & 3,8 & 4,11 & 4,31 & 4,80 & 3,94 & 3,65 & 4,08 & 3,97 & 3,97 & 4,02 & 3,66 & 3,63 & 4,28 & 3,89 \\
\hline & DT & 1,47 & 1,25 & 1,35 & 1,25 & 1,15 & 1,05 & 0,57 & 1,14 & 1,28 & 1,05 & 1 & 1,1 & 1,43 & 1,35 & 1,33 & I,08 & 1,21 \\
\hline Average & 4,27 & 4,24 & 3,74 & 4,13 & 4,08 & 4,28 & 4,62 & 3,97 & 3,66 & 4,05 & 4,10 & 4,00 & 4,15 & 3,42 & 3,66 & 4,12 & 3,87 & 4,27 \\
\hline
\end{tabular}

However, although this result complies with the first principle, it fails to comply with the second principle by not considering the opinions of other groups with an entity within the different sectors. Therefore, under the assumption that guides the analysis, to achieve maximum representativeness, it is necessary to explore each sector internally and consider the proposals of internal groups, so it is necessary to analyze the results of each sector individually and, subsequently, to unify them according to the designed procedure. When analyzing the distribution of the results of the families (Table 1), we obtain that, for these, the Respect (4.71) is the most important value, followed by the Assertiveness (4.47), the Courtesy (4.45)),
Equality $(4,43)$, Will $(4,42)$, Self-control $(4,41)$, Responsibility $(4,41)$, Cleaning $(4,40)$, Sincerity $(4,36)$ and the Forgiveness $(4,22)$. Considering the sex of the tutor of the student (Table 2), we observe that, for both men and women, the most valued value is Respect (4.45, men, 4.85, women), followed, in the case of men, Self-control (4.29), Courtesy (4.19), Assertiveness (4.16), Equality (4.16), Cleanliness (4.16), Will (4.13), the Responsibility (4.06), Forgiveness (3.97) and Sincerity (3.97). In the case of women, Respect is followed by Assertiveness (4.64), Responsibility (4.60), Courtesy (4.60), Will (4.58), and Sincerity (4.58), Equality $(4,58)$, Cleanliness $(4,53)$, Selfcontrol $(4,47)$, Empathy $(4,36)$ and Forgiveness $(4,36)$ (Table 2).

Table 2 Results by sex (N, sample; DT, standard deviation; M, Medium)

\begin{tabular}{|c|c|c|c|c|c|c|c|c|c|c|c|c|c|c|c|c|c|c|}
\hline Sex & $\begin{array}{l}\text { Medium/ } \\
\text { Standard } \\
\text { Desviation }\end{array}$ & $\begin{array}{l}\text { Equa- } \\
\text { lity }\end{array}$ & $\begin{array}{l}\text { Affec- } \\
\text { tivity }\end{array}$ & $\begin{array}{l}\text { Clea- } \\
\text { ning }\end{array}$ & $\begin{array}{l}\text { Asserti- } \\
\text { veness }\end{array}$ & $\begin{array}{c}\text { Self- } \\
\text { control }\end{array}$ & $\begin{array}{l}\text { Cour- } \\
\text { tesy }\end{array}$ & $\begin{array}{l}\text { Res- } \\
\text { pect }\end{array}$ & $\begin{array}{l}\text { Auto- } \\
\text { nomy }\end{array}$ & $\begin{array}{l}\text { Reflec- } \\
\text { tion }\end{array}$ & $\begin{array}{l}\text { Em- } \\
\text { pathy }\end{array}$ & $\begin{array}{c}\text { Since- } \\
\text { rity }\end{array}$ & $\begin{array}{l}\text { Forgi- } \\
\text { veness }\end{array}$ & $\begin{array}{l}\text { Respon- } \\
\text { sibility }\end{array}$ & $\begin{array}{l}\text { Pro- } \\
\text { welfare }\end{array}$ & $\begin{array}{l}\text { Cou- } \\
\text { rage }\end{array}$ & Will & $\begin{array}{l}\text { Intercul- } \\
\text { turality }\end{array}$ \\
\hline \multirow{2}{*}{$\begin{array}{c}\operatorname{Man} \mathbf{N} \\
=31\end{array}$} & M & 4,16 & 4,16 & 3,84 & 4,16 & 4,29 & 4,19 & 4,45 & 3,74 & 3,58 & 3,71 & 3,97 & 3,97 & 4,06 & 3,61 & 3,42 & 4,13 & 3,52 \\
\hline & DT & $\mathrm{I}, \mathrm{I}$ & I,I & I,I & 1,00 & ,78 & 1,08 & 1,12 & 1,09 & 1,26 & 1,13 & 1,40 & 1,08 & 1,18 & 1,15 & 1,38 & 1,23 & 1,44 \\
\hline \multirow{2}{*}{$\begin{array}{c}\text { Women } \\
\mathrm{N}=55\end{array}$} & M & 4,58 & 4,53 & 4,09 & 4,64 & 4,47 & 4,60 & 4,85 & 4,31 & 4,13 & 4,36 & 4,58 & 4,36 & 4,60 & 4,13 & 4,18 & 4,58 & 4,04 \\
\hline & DT & 94 & ,72 & ,95 & 65 & ,94 & ,74 & ,36 & ,92 & $\mathrm{I}, 04$ & ,78 & 68, &, 85 & ,6 & I,II & ,93 & 66 & 98 \\
\hline
\end{tabular}

Regarding possible differences of opinion depending on the origin or nationality of the families, although the surveys collected this information, we could not establish a consistent grouping due to the high dispersion of origins and the small sample size of each one. When we analyze the results according to the level of studies of the father, mother or tutor of the student (Table 3), we observe that the

Table 3 Results of families according to academic training (N, sample; DT, standard deviation; M, Medium)

\begin{tabular}{|c|c|c|c|c|c|c|c|c|c|c|c|c|c|c|c|c|c|c|}
\hline Training & $\begin{array}{c}\text { Medium/ } \\
\text { Standard } \\
\text { Desviation }\end{array}$ & $\begin{array}{l}\text { Equa- } \\
\text { lity }\end{array}$ & $\begin{array}{l}\text { Clean- } \\
\text { liness }\end{array}$ & $\begin{array}{l}\text { Affec- } \\
\text { tivity }\end{array}$ & $\begin{array}{l}\text { Asser- } \\
\text { tive- } \\
\text { ness }\end{array}$ & $\begin{array}{l}\text { Auto } \\
\text { control }\end{array}$ & $\begin{array}{l}\text { Cour- } \\
\text { tesy }\end{array}$ & $\begin{array}{l}\text { Res- } \\
\text { pect }\end{array}$ & $\begin{array}{l}\text { Auto- } \\
\text { nomy }\end{array}$ & $\begin{array}{l}\text { Reflec- } \\
\text { tion }\end{array}$ & $\begin{array}{c}\text { Em- } \\
\text { pathy }\end{array}$ & $\begin{array}{l}\text { Since- } \\
\text { rity }\end{array}$ & $\begin{array}{l}\text { Forgi- } \\
\text { veness }\end{array}$ & $\begin{array}{c}\text { Res- } \\
\text { ponsi- } \\
\text { bility }\end{array}$ & $\begin{array}{l}\text { Pro- } \\
\text {-wel- } \\
\text { fare }\end{array}$ & $\begin{array}{l}\text { Cou- } \\
\text { rage }\end{array}$ & Will & $\begin{array}{l}\text { Intercul- } \\
\text { turality }\end{array}$ \\
\hline EP & M & 4,53 & 4,65 & 4,12 & $4,4 I$ & 4,53 & 4,71 & 4,94 & 4,06 & 3,59 & 4,24 & 4,65 & 4,47 & 4,59 & 3,94 & 3,76 & $4,4 I$ & 3,59 \\
\hline$N=17$ & DT & ,87 & 61 &, 7 & ,71 & 62 & ,59 & 24 & ,75 & 1,28 & ,83 & ,70 & , 80 & ,62 &, 9 & ,90 & 1,06 & ,94 \\
\hline ESO & M & 4,28 & 4,44 & 3,91 & 4,56 & 4,44 & 4,53 & 4,69 & 4,06 & 3,94 & 4,06 & 4,31 & 4,22 & 4,38 & 3,91 & 3,97 & 4,44 & 3,84 \\
\hline $\mathrm{N}=36$ & DT & 1,11 & ,84 & 1 & ,72 & ,84 & , 80 & ,82 & 1,27 & 1,16 & ,98 &, 9 & ,91 & ,87 & 1,35 & 1,12 & 84 & 1,19 \\
\hline$N=17$ & DT & 69 & ,70 & 1,05 & ,87 & 1,29 & ,90 & ,61 & ,81 & 88 & ,83 & ,8 & 69 & ,72 & ,93 & ,81 & ,62 & ,99 \\
\hline
\end{tabular}

scores for Cleanliness, Courtesy, Sincerity and Forgiveness decrease as the educational level increases. On the other hand, Reflection increases directly with the highest level of training. However, different hierarchies of values are not observed depending on the level of training (Table 3). 
We can conclude that for families, regardless of gender and educational level, the fundamental value is Respect; but, when considering sex, the other values vary. The following table shows the global hierarchy of families, that of parents or guardians and those of mothers or tutors. At the intersection of both sets, and following the procedure designed to order them, we obtain the proposed hierarchy for this sector: Respect (4.71), Assertiveness (4.47), Courtesy (4.45), Equality (4.43), Will $(4,42)$, Self-control $(4,41)$, Responsibility $(4,41)$, Cleaning $(4,40)$, Sincerity $(4,36)$, Forgiveness $(4,22)$ and Empathy $(4,13)$ (Table 4).

Table 4 Proposal for synthesis of the family sector (N, sample; DT, standard deviation; M, Medium)

\begin{tabular}{|c|c|c|c|c|c|c|c|c|c|c|c|c|c|c|c|c|c|c|}
\hline \multicolumn{2}{|c|}{ Hierarchies } & \multicolumn{17}{|c|}{ Values of families } \\
\hline \multicolumn{2}{|c|}{ Global } & \multicolumn{17}{|c|}{ Respect (4.7I), Assertiveness (4.47), Courtesy (4.45), Equality (4.43), Will (4.42), Self-control (4.4I), Responsibility (4.4I), Cleaning (4.40), Sincerity (4.36) and Forgiveness (4.22) } \\
\hline \multicolumn{2}{|l|}{ Men } & \multicolumn{17}{|c|}{ Respect (4.45), Self-control (4.29), Courtesy (4.19), Assertiveness (4.16), Equality (4.16), Cleanliness (4.16), Will (4.13), Responsibility (4.06), Forgiveness (3.97) and Sincerity (3.97) } \\
\hline \multicolumn{2}{|c|}{ Women } & \multicolumn{17}{|c|}{$\begin{array}{l}\text { Respect (4.85), Assertiveness (4.64), Responsibility (4.60), Courtesy (4.60), Will (4.58), Sincerity (4.58), Equality (4.58), Cleanliness (4.53), Self-control (4.47), Empathy (4.36) and Forgiveness } \\
\text { (4.36) }\end{array}$} \\
\hline \multicolumn{2}{|c|}{$\begin{array}{l}\text { Proposal by } \\
\text { families }\end{array}$} & \multicolumn{17}{|c|}{$\begin{array}{l}\text { Respect (4.7I), Assertiveness (4.47), Courtesy (4.45), Equality (4.43), Will (4.42), Self-control (4.4I), Responsibility (4.4I), Cleaning (4.40), Sincerity (4.36), Forgiveness (4.22) and Empathy } \\
\qquad(4.13)\end{array}$} \\
\hline \multicolumn{9}{|c|}{$\begin{array}{l}\text { In the case of students, globally (Table } 1) \text {, the value that most } \\
\text { concerns is Equality, with an average score of } 4.47 \text {, followed by } \\
\text { Respect ( } 4.36) \text {, Cleaning }(4.22) \text {, Assertiveness }(4,13) \text {, Courtesy } \\
(4,07) \text {, Responsibility }(4,01) \text { and Sincerity }(3,98) \text {. When we observe } \\
\text { the data according to the sex of the student (Table } 5) \text {, we verify that, for } \\
\text { men, the priority values are Equality }(4.33) \text {, Respect }(4.27) \text {, Cleaning }\end{array}$} & \multicolumn{10}{|c|}{$\begin{array}{l}\text { (4.15), Assertiveness (4.09), Courtesy (3.97), Sincerity (3.85), } \\
\text { Empathy (3.84) and Responsibility (3.83). In the case of women, they } \\
\text { are Equality (4.58), Respect (4.43), Cleanliness (4.28), Responsibility } \\
\text { (4.17), Assertiveness (4.16), Courtesy.(4.15), and Sincerity (4.09), } \\
\text { which is a remarkable coincidence in their hierarchies of values } \\
\text { (Table 5). }\end{array}$} \\
\hline Sex & & $\begin{array}{l}\text { Equa- } \\
\text { lity }\end{array}$ & $\begin{array}{l}\text { Af- } \\
\text { fecti- } \\
\text { vity }\end{array}$ & $\begin{array}{l}\text { Clea- } \\
\text { ning }\end{array}$ & $\begin{array}{l}\text { As- } \\
\text { ser- } \\
\text { tive- } \\
\text { ness }\end{array}$ & $\begin{array}{l}\text { Self- } \\
\text {-con- } \\
\text { trol }\end{array}$ & $\begin{array}{c}\text { Cour- } \\
\text { tesy }\end{array}$ & $\begin{array}{l}\text { Res- } \\
\text { pect }\end{array}$ & $\begin{array}{l}\text { Auto- } \\
\text { nomy }\end{array}$ & $\begin{array}{l}\text { Re- } \\
\text { flec- } \\
\text { tion }\end{array}$ & $\begin{array}{l}\text { Em- } \\
\text { pa- } \\
\text { thy }\end{array}$ & $\begin{array}{l}\text { Sin- } \\
\text { ceri- } \\
\text { ty }\end{array}$ & $\begin{array}{l}\text { For- } \\
\text { give- } \\
\text { ness }\end{array}$ & $\begin{array}{c}\text { Res- } \\
\text { ponsi- } \\
\text { bility }\end{array}$ & $\begin{array}{c}\text { Pro- } \\
\text { welfare }\end{array}$ & $\begin{array}{l}\text { Cou- } \\
\text { rage }\end{array}$ & Will & $\begin{array}{c}\text { Intercul- } \\
\text { turality }\end{array}$ \\
\hline \multirow{2}{*}{$\begin{array}{c}\operatorname{men}_{\mathrm{N}=126} \\
\text {. }\end{array}$} & M & 4,33 & 4,15 & 3,52 & 4,09 & 3,55 & 3,97 & 4,27 & 3,75 & 3,34 & 3,84 & 3,85 & 3,67 & 3,83 & 2,43 & 3,28 & 3,44 & 3,72 \\
\hline & DT & 1,16 & 1,13 & $|, 5|$ & I,I & 1,32 & 1,17 & I,I & 1,18 & I,34 & 1,22 & 1,26 & 1,34 & 1,15 & 1,51 & I,34 & 1,42 & 1,33 \\
\hline \multirow{2}{*}{$\begin{array}{l}\text { Woman } \\
N=147\end{array}$} & $M$ & 4,58 & 4,28 & 3,87 & 4,16 & 3,85 & 4,15 & 4,43 & 3,98 & 3,45 & 4,02 & 4,09 & 3,92 & 4,17 & 2,86 & 3,60 & 3,86 & 4,01 \\
\hline & DT & ,91 & ,95 & 1,19 & 1,01 & 1,13 & 1,01 & 99 & 1,13 & 1,28 & $\mid, 21$ & 1,02 & 1,21 & ,93 & 1,34 & 1,24 & 1,22 & 1,09 \\
\hline
\end{tabular}

If we analyze the trends along the different levels (Table 6), we observe that Equality, Respect and Well-being increase progressively as the level of education progresses, with a difference of 0.5 points between the first and second years and Baccalaureate. An even greater difference is seen with Empathy, since the variable presents a distribution curve that would peak in $3^{\circ}$ of ESO, with an increase of 0.82 points, and that would decrease again in the upper grades. When treating the different opinions according to the level studied (Table 6), we obtain that, in the first year of ESO, the proposed hierarchy is Equality (4.29), Cleanliness (4.24), Respect (4.18), Courtesy (4.08), Sincerity (4.06), Assertiveness (4.02), Forgiveness
(3.98) and Responsibility (3.98). In the second year, the classification is: Respect (4.45), Equality (4.41), Empathy (4.30), Cleaning (4.30), Assertiveness (4.27), Responsibility (4,23), Interculturality (4,17), Courtesy (4,13), Forgiveness $(4,11)$ and Sincerity $(4,04)$. In the third year, we find the following order: Equality (4.65), Empathy (4.58), Respect (4.50), Autonomy (4.35), and Cleanliness (4.31). In the fourth year, we observed the following gradation: Equality (4.46), Respect (4.26), Assertiveness (4.14), Cleanliness (4.11), Sincerity (3.98) and Autonomy (3.96). ). And, finally, in the Baccalaureate, the proposed hierarchy is: Equality (4.78), Respect (4.67), Courtesy (4.37) and Cleaning (4.30) (Table 6)

Table 6 Results of the students by educational levels (N, sample; DT, standard deviation; M, Medium)

\begin{tabular}{|c|c|c|c|c|c|c|c|c|c|c|c|c|c|c|c|c|c|c|}
\hline Course & & $\begin{array}{l}\text { Equa- } \\
\text { lity }\end{array}$ & $\begin{array}{l}\text { Affec- } \\
\text { tivity }\end{array}$ & $\begin{array}{l}\text { Clea- } \\
\text { ning }\end{array}$ & $\begin{array}{l}\text { Asserti- } \\
\text { veness }\end{array}$ & $\begin{array}{l}\text { Self- } \\
\text {-con- } \\
\text { trol }\end{array}$ & $\begin{array}{c}\text { Cour- } \\
\text { tesy }\end{array}$ & $\begin{array}{l}\text { Res- } \\
\text { pect }\end{array}$ & $\begin{array}{l}\text { Auto- } \\
\text { nomy }\end{array}$ & $\begin{array}{l}\text { Re- } \\
\text { flec- } \\
\text { tion }\end{array}$ & $\begin{array}{c}\text { Em- } \\
\text { pathy }\end{array}$ & $\begin{array}{c}\text { Since- } \\
\text { rity }\end{array}$ & $\begin{array}{l}\text { Forgi- } \\
\text { veness }\end{array}$ & $\begin{array}{l}\text { Respon- } \\
\text { sibility }\end{array}$ & $\begin{array}{l}\text { Pro- } \\
\text {-wel- } \\
\text { fare }\end{array}$ & $\begin{array}{l}\text { Cou- } \\
\text { rage }\end{array}$ & Will & $\begin{array}{l}\text { Inter- } \\
\text { cultu- } \\
\text { rality }\end{array}$ \\
\hline \multirow{2}{*}{$\begin{array}{l}I^{\circ} E S O \\
N=51\end{array}$} & $M$ & 4,29 & 4,24 & 3,39 & 4,02 & 3,31 & 4,08 & 4,18 & 3,49 & 3,24 & 3,76 & 4,06 & 3,98 & 3,98 & 2,73 & 3,57 & 3,71 & 3,65 \\
\hline & DT & 1,33 & 1,19 & 1,33 & ,88 & 1,39 & 1,09 & I,07 & $\mathrm{I}, 30$ & I,45 & 1,37 & 1,09 & 1,26 & 1,27 & 1,46 & 1,51 & 1,49 & 1,34 \\
\hline \multirow{2}{*}{$\begin{array}{l}2^{\circ} \mathrm{ESO} \\
\mathrm{N}=71\end{array}$} & $M$ & 4,41 & 4,30 & 3,68 & 4,27 & 3,89 & 4,13 & 4,45 & 3,83 & 3,28 & 4,30 & 4,04 & 4,11 & 4,23 & 2,48 & 3,35 & 3,83 & 4,17 \\
\hline & DT & 950 & 1,02 & 1,35 & 1,06 & 1,32 & 1,04 & ।,07 & 1,38 & 1,28 & 1,06 & 1,15 & 1,01 & 8 & 1,52 & $\mathrm{I}, 42$ & 1,15 & I,04 \\
\hline \multirow{2}{*}{$\begin{array}{c}3^{\circ} \mathrm{ESO} \\
\mathrm{N}=26\end{array}$} & $M$ & 4,65 & 4,31 & 4,04 & 4,04 & 4,00 & 4,08 & 4,50 & 4,35 & 3,96 & 4,58 & 3,58 & 3,85 & 4,04 & 2,85 & 3,58 & 3,38 & 3,54 \\
\hline & DT & ,69 & ,88 & 1,61 & 1,08 & 1,06 & 1,2 & $\mathrm{I}, \mathrm{II}$ & ,75 & ,77 & ,70 & $\mathrm{I}, 47$ & 1,19 & 1,18 & 1,29 & 1,14 & 1,75 & 1,33 \\
\hline \multirow{2}{*}{$\begin{array}{c}4^{\circ} \text { ESO } \\
\mathrm{N}=98\end{array}$} & $M$ & 4,46 & 4,11 & 3,86 & 4,14 & 3,64 & 3,93 & 4,26 & 3,96 & 3,33 & 3,69 & 3,98 & 3,48 & 3,84 & 2,56 & 3,38 & 3,55 & 3,90 \\
\hline & DT & $\mathrm{I}, \mathrm{II}$ & 1,06 & 1,34 & $\mathrm{I}, \mathrm{II}$ & 1,17 & 1,14 & 1,09 & 1,03 & 1,42 & 1,29 & 1,14 & 1,43 & 1,09 & 1,49 & 1,21 & 1,33 & 1,23 \\
\hline \multirow{2}{*}{$\begin{array}{l}\text { BACH } \\
\mathbf{N}=27\end{array}$} & $M$ & 4,78 & 4,30 & 3,52 & 4,00 & 3,96 & 4,37 & 4,67 & 3,96 & 3,74 & 3,59 & 4,04 & 3,81 & 4,15 & 3,19 & 3,63 & 3,85 & 3,81 \\
\hline & DT & .42 &, 78 & 1,09 & 1,07 & 81 & 84 &, 56 & 8 & .90 & 1,05 & .81 & 1,24 & .82 & .92 & 1,01 & .99 & 1,11 \\
\hline
\end{tabular}


We can conclude that, for students of all levels (both men and women), Equality is the main value, except for the second of ESO, which puts Respect first. The following table shows the global hierarchy of the students and those of each level. To compose the hierarchy of the sector, we follow the procedure designed, obtaining from the intersection of all the sets the values Equality, Respect and Cleaning. Courtesy appears in seven groups; in six, Assertiveness; in four, the Responsibility, Assertiveness and Sincerity; in three, Empathy; in two, the Forgiveness and Autonomy; and in one, Interculturality. The final proposal of the student sector would be as follows: Equality (4.47), Respect (4.36), Cleanliness (4.22), Courtesy (4.07), Assertiveness (4.13), Responsibility (4, 01), Sincerity (3.98), Empathy (3.94), Forgiveness (3.81), Autonomy (3.88) and Interculturality (3.88) (Table 7).

Table 7 Proposal for synthesis of the student sector (N, sample; DT, standard deviation; M, Medium)

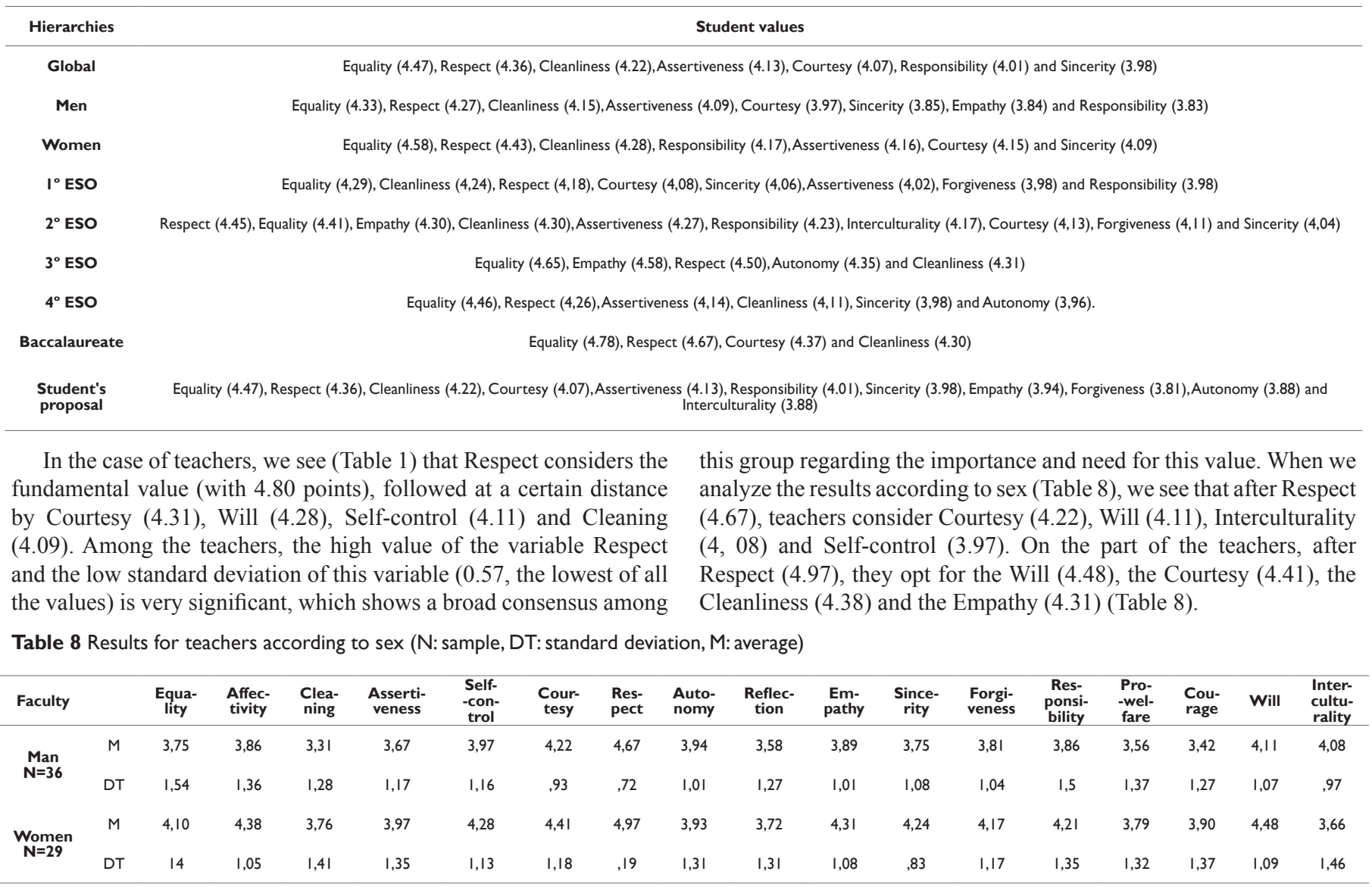

If we analyze the data according to the age range (Table 9), we see than 46 years proposed: Respect (4.65), Will (4.47), Self-control that teachers under 34 years of age propose the following hierarchy: (4.18), Autonomy (4.12) and Courtesy (4.06). Respect remains the Respect (4.78), Empathy (4.56), Courtesy (4.44), Forgiveness (4.33) priority value in each timeframe, followed by Courtesy (the second and Interculturality (4.33). For teachers between 35 and 46 years, the most important for the elderly and the third for the rest). For those proposed hierarchy is: Respect (4.87), Cleanliness (4.44), Courtesy of medium and greater age, the next value would be the Self-control (4.38), Will (4.21), Self-control (4.15). For its part, teachers older (Table 9).

Table 9 Results for teachers according to age range (N, sample; DT, standard deviation; M, Medium)

\begin{tabular}{|c|c|c|c|c|c|c|c|c|c|c|c|c|c|c|c|c|c|c|}
\hline $\begin{array}{c}\text { Age } \\
\text { (Teaching } \\
\text { staff) }\end{array}$ & & $\begin{array}{l}\text { Equa- } \\
\text { lity }\end{array}$ & $\begin{array}{l}\text { Af- } \\
\text { fecti- } \\
\text { vity }\end{array}$ & $\begin{array}{l}\text { Clea- } \\
\text { ning }\end{array}$ & $\begin{array}{l}\text { Asser- } \\
\text { tive- } \\
\text { ness }\end{array}$ & $\begin{array}{l}\text { Self- } \\
\text {-con- } \\
\text { trol }\end{array}$ & $\begin{array}{l}\text { Cour- } \\
\text { tesy }\end{array}$ & $\begin{array}{l}\text { Res- } \\
\text { pect }\end{array}$ & $\begin{array}{l}\text { Auto- } \\
\text { nomy }\end{array}$ & $\begin{array}{l}\text { Re- } \\
\text { flec- } \\
\text { tion }\end{array}$ & $\begin{array}{l}\text { Em- } \\
\text { pa- } \\
\text { thy }\end{array}$ & $\begin{array}{l}\text { Sin- } \\
\text { ceri- } \\
\text { ty }\end{array}$ & $\begin{array}{l}\text { For- } \\
\text { give- } \\
\text { ness }\end{array}$ & $\begin{array}{l}\text { Res- } \\
\text { ponsi- } \\
\text { bility }\end{array}$ & $\begin{array}{l}\text { Pro- } \\
\text {-wel- } \\
\text { fare }\end{array}$ & $\begin{array}{l}\text { Cou- } \\
\text { rage }\end{array}$ & Will & $\begin{array}{l}\text { Inter- } \\
\text { cultu- } \\
\text { rality }\end{array}$ \\
\hline $23-34$ & $M$ & 4,22 & 3,44 & 3,67 & 4,00 & 3,78 & 4,44 & 4,78 & 4,11 & 3,11 & 4,56 & 4,22 & 4,33 & 4,22 & 4,11 & 3,89 & 4,22 & 4,33 \\
\hline$N=9$ & DT & ,97 & 1,42 & I,58 & 1,00 & I,56 & ,88 & ,67 & ,93 & 1,27 & ,73 & ,667 & ,71 & 1,64 & ,93 & ,78 & ,67 & ,71 \\
\hline $35-46$ & $M$ & 3,90 & 4,44 & 3,49 & 3,77 & 4,15 & 4,38 & 4,87 & 3,82 & 3,62 & 4,00 & 4,08 & 4,00 & 4,00 & 3,62 & 3,64 & 4,21 & 3,82 \\
\hline $\mathrm{N}=39$ & DT & 1,37 & 1 & I,45 & 1,25 & 1,18 & I,, 07 & ,34 & 1,36 & 1,37 & 1,13 & ,98 & 1,19 & 1,50 & 1,46 & I,44 & 1,17 & I,43 \\
\hline$>47$ & $M$ & 3,76 & 3,65 & 3,47 & 3,76 & 4,18 & 4,06 & 4,65 & 4,12 & 4,00 & 4,00 & 3,59 & 3,71 & 3,94 & 3,53 & 3,47 & 4,47 & 3,82 \\
\hline$N=17$ & DT & 1,89 & 1,46 & 1,01 & I,44 & ,81 & 1,09 & ,86 & ,60 & 1,00 & 1,00 & 1,12 & 1,05 & 1,2 & 1,23 & 1,33 & I,, 07 & ,81 \\
\hline Total & $M$ & 3,91 & 4,09 & 3,51 & 3,80 & 4,11 & 4,31 & 4,80 & 3,94 & 3,65 & 4,08 & 3,97 & 3,97 & 4,02 & 3,66 & 3,63 & 4,28 & 3,89 \\
\hline$N=65$ & DT & $\mathrm{I}, 47$ & 1,25 & 1,35 & 1,25 & 1,15 & 1,05 & ,57 & 1,14 & 1,28 & 1,05 & 1,00 & 1,10 & 1,43 & 1,34 & 1,33 & 1,08 & $|, 2|$ \\
\hline
\end{tabular}


In summary, as shown in the following table, the hierarchy that would best reflect the values of the teaching staff would be: Respect (4.80), Courtesy (4.31), Will (4.28), Self-control (4.11), Cleanliness (4.09), Empathy (4.08) and Interculturality (3.89) (Table 10).

Once the proposal of each educational sector is finalized, the last step is to combine these proposals into a unified one (Table 11). Following the designed procedure, the final hierarchy will be shaped, firstly, by the values that arise from the intersection of the three sectors, resulting in the set \{Respect (4.62), Courtesy (4.28), Cleanliness $(4,24)\}$. These are the values with the greatest global consensus and, therefore, are the fundamental basis of the center's hierarchy of values. On this general consensus we observe other partial agreements: in particular, both families and teachers affect the values of Self Control and Will. Cleaning appears between the teachers and the students; and, finally, students and families agree on Equality, Assertiveness and Responsibility. Therefore, the following set will be Equality $(4,27)$, Assertiveness $(4,13)$, Self-control $(4,08)$, Responsibility (4,15), Sincerity (4,10), Forgiveness (4), Empathy ( 4.05), Interculturality (3.87) $\}$ and, finally, the set of values formed by the particular proposals \{Will (4.12), Autonomy (3.97)\} (Table 11).

Table 10 Results for teachers according to age range (N: sample, DT: standard deviation, M: average)

\begin{tabular}{cr}
\hline Stock & Hierarchies \\
\hline $\begin{array}{c}\text { Global } \\
\text { Men }\end{array}$ & Respect (4.80), Courtesy (4.3I), Will (4.28), Self-control (4.II) and Cleaning (4.09) \\
Women & Respect (4.67), Courtesy (4.22), Will (4.I I), Interculturality (4.08) and Self-control (3.97) \\
23-34 years & Respect (4.97), Will (4.48), Courtesy (4.4I), Cleanliness (4.38) and Empathy (4.3I) \\
35-46 years & Respect (4.78), Empathy (4.56), Courtesy (4.44), Forgiveness (4.33) and Interculturality (4.33) \\
Over $\mathbf{4 6}$ years old & Respect (4.87), Cleanliness (4.44), Courtesy (4.38), Will (4.2I), Self-control (4.I5) \\
Teacher proposal & Respect (4.65), Will (4.47), Self-control (4.I8), Autonomy (4.I2) and Courtesy (4.06) \\
\hline
\end{tabular}

Table I I Final Hierarchy (N, sample; DT, standard deviation; M, Medium)

\begin{tabular}{|c|c|}
\hline Stock & Hierarchies \\
\hline Global & Respect (4.62), Courtesy (4.28), Equality (4.27), Cleanliness (4.24) and Responsibility (4.I5) \\
\hline Families & $\begin{array}{c}\text { Respect (4.7I), Assertiveness (4.47), Courtesy (4.45), Equality (4.43), Will (4.42), Self-control (4.4I), Responsibility (4.4I), Cleaning (4.40), } \\
\text { Sincerity (4.36), Forgiveness (4.22) and Empathy (4.I3) }\end{array}$ \\
\hline Student & $\begin{array}{c}\text { Equality (4.47), Respect (4.36), Cleanliness (4.22), Courtesy (4.07), Assertiveness (4.13), Responsibility (4.01), Sincerity (3.98), Empathy (3.94), } \\
\text { Forgiveness (3.8I), Autonomy (3.88) and Interculturality (3.88) }\end{array}$ \\
\hline Faculty & Respect (4.80), Courtesy (4.3I),Will (4.28), Self-control (4.II), Cleanliness (4.09), Empathy (4.08) and Interculturality (3.89) \\
\hline $\begin{array}{l}\text { Final } \\
\text { Proposal }\end{array}$ & $\begin{array}{c}\{\text { Respect (4.62), Courtesy (4.28), Cleanliness }(4.24)\}+\{\text { Equality (4.27), Assertiveness }(4.13) \text {, Self-control }(4.08), \text { Responsibility }(4.15)) \\
\text { Sincerity }(4,10) \text {, Forgiveness (4), Empathy }(4,05) \text {, Interculturality }(3,87)\}+\{\text { Will }(4,12), \text { Autonomy }(3,97)\}\end{array}$ \\
\hline
\end{tabular}

\section{Discussion and conclusion}

In the study we have seen how each educational sector has a particular vision of the values that are most necessary to promote. However, the different views agree that Respect is the priority value. Both for families and for teachers is the most valued value above the rest. The families have awarded 4.71 points and the teaching staff, 4.80 points; however, the students value more Equality (4.47), although very close and, secondly, Respect also appears (4.36). It is necessary to highlight the assessment that teachers make about Respect, giving them 4.80 points (the highest score among all the evaluations and for all sectors). In addition, the standard deviation is 0.57 , the lowest of all, which denotes an extraordinary consensus among teachers at this point. In the same line, the average valuation among the three sectors is 4.62 , well above the next value. Consequently, the data are a clear indicator that Respect is a great concern and must be addressed in a firm manner in the action plans. The second value of the hierarchy is Courtesy, a result consistent with the previous one, given the close relationship of meanings between Respect and Courtesy. Courtesy is recognized as very important by the three educational sectors, being the second most important value for teachers, the third for families and the fourth for students. The third value claimed by the three sectors is Cleaning, although this appears in more distant positions, being the third value for students, the fifth for teachers and the eighth for families. We believe that this broad consensus should be used to address lines of action that improve Respect, Courtesy and Cleanliness. Also, taking into account the demands of the groups and particular sectors, the values of the rest of the hierarchy should be taken into account: Equality, Assertiveness, Self-control, Responsibility, Sincerity, Forgiveness, Empathy, Interculturality, Will and Autonomy. Undoubtedly, all values are relevant, but a hierarchy of values is precisely a way of prioritizing, of focusing effort and attention on what matters most or is most necessary and urgent. To conclude, we would like to emphasize that listening to the whole community is, without a doubt, a democratic and participatory process that facilitates the more accurate determination of the reality of the center, the values that most concern and the values most desired. But, in addition to listening to everyone, procedures must be created that consider the demands of all sectors and minority groups. In the analyzed project, both propositions have been fulfilled, achieving that the resulting hierarchy represents faithfully the general demands of the three sectors of the school community and gives presence to the opinions of the different groups that make up each sector. Therefore, it is the best starting point to develop your own action plan. 


\section{Acknowledgment}

None.

\section{Conflict of interest}

None.

\section{References}

1. Schramm Martín C. Values and educational reform. Pedagogy Magazine. Spain.1990;42(3):267-273.

2. Lomce. Organic Law, for the improvement of educational quality. Official State Gazette, nº 295. 2013 Dec 10;UK: p.97858-97921.

3. Ortega y Gasset J. Complete works. Madrid: Magazine of the West. Spain.1973;(4):280-325.

4. Rokeach M. The nature of human values. Free Press. New York: 1973 438 p.

5. Sanmartin Arce R. Ethnography of values. Theory of Education. 2000;(12):129-141.

6. Sánchez Vera F. Challenges and realities of education in values. In Sánchez Vera F, Diego Marín (Coord), editors. Perspectives of the teaching staff. Spain:2016;5-30.

7. Gervilla Castillo E. An axiological model of integral education. Spanish journal of pedagogy. 2000;(215):39-58.

8. Piñero E, Arense, JJ, López JJ, et al. Incidence of violence and school victimization in students of compulsory secondary education in the Region of Murcia. Educational Research Journal. 2014;32(1):223-241.

9. Díaz MJ, Martínez R, Martín J. State study of school coexistence in Compulsory Secondary Education. Ministry of Education. Spain: 2010.380 p.

10. Gotzens C, Badía C, Genovard C, et al. Comparative study of the severity attributed to disruptive behavior in the classroom. Electronic Journal of Research in Educational Psychology. 2010;8(20):33-58.

11. Orts JV. How to teach to those who do not want. Grao, editor. Spain:2011.

12. Belda JF. Social participation in the school: a collective challenge. Anthropos. 2013;238(1):83-102.

13. Valls R, Kyriakides L. The power of interactive groups: how diverse of adults volunteering in classroom groups can promote inclusion and success for children of vulnerable ethnic populations. Cambridge Journal of Education. 2013;43(1):17-33.
14. Flecha R, Villarejo B. Critical Pedagogy: An Approach to the Real Right of Education. International Journal of Education for Social Justice (RIEJS). 2015;4(2):87-100.

15. Arostegui I, Darretxe L, Beloki N, et al. The participation of families and other members of the community as a strategy of success in schools. Iberoamerican Magazine of Educational Evaluation. 2013;6(2):187200.

16. Jurado P, Justiniano MD. Intervention proposals for disruptive behavior in Compulsory Secondary Education. Spanish Journal of Counseling and Psychopedagogy. 2016;27(3):8-25.

17. Andrés S, Giró J The role and representation of teachers in the participation of families in school. Interuniversity Electronic Journal of Teacher Training. 2016:19(1):61-71.

18. School Council of the State. The relationships between family and school. Experiences and good practices. XXIII Meeting of Autonomous and State School Councils. USA: 2015.484 p.

19. Llevot N, Bernard O. The participation of families in the school key factors. Journal of the Association of Sociology of Education. 2015;8(1):57-60.

20. Calvo MI, Verdugo MÁ, Amor AM, et al. Family participation is an essential requirement for an inclusive school. Latin American Journal of Inclusive Education 2016;10(1):99-113.

21. Bolivar A. Family and school: two worlds called to work in common. Journal of Education 2006;339(2):119-146.

22. García Carrión R. Schools as Learning Communities. International Review of Qualitative Research. 2016;9(2):152-164.

23. Vallespir J, Rincón JC, Morey M. The participation of families in the School Council and teacher training. Interuniversity Electronic Journal of Teacher Training. 2016;19(1):31-45

24. Povedano A, Cava MJ, Monreal MC. Et al. Victimization, loneliness, overt and relational violence at the school from a gender perspective. International Journal of Clinical and Health Psychology. 2015;15(1):4451.

25. Álvarez-García D, Dobarro A, Rodríguez C, et al. The consensus of classroom norms and their relationship with low levels of school violence. Childhood and Learning. 2013;36(2):199-217.

26. Arrow R. Successful Educational Actions for Inclusion and Social Cohesion in Europe. Springer International Publishing. 1st ed. UK: 2015. 